\title{
Comparison of Different Methods for Evaluating Resin Composite Restorations in Posterior Teeth
}

\author{
Comparação de Diferentes Métodos para Avaliação de Restaurações de Resina Composta em \\ Dentes Posteriores
}

Karina Podestá ${ }^{1}$, Juliana Jobim Jardim², Maurício dos Santos Moura ${ }^{3}$, Marisa Maltz ${ }^{4}$

\section{Resumo}

Objetivo: Comparar diferentes métodos para avaliação de restaurações de resina composta em dentes posteriores e avaliar a confiabilidade de cada método através da determinação de concordância intraexaminador. Materiais e Métodos: 136 restaurações Classe I de resina composta foram avaliadas por um examinador treinado utilizando o critério de Ryge modificado através três métodos diferentes: clínico, fotográfico e modelos de gesso. Resultados: Os resultados mostraram que a concordância intraexaminador foi melhor em avaliação em modelos de gesso para integridade marginal e forma anatômica, e foi similar entre fotografias e avaliação clínica para integridade marginal e descoloração marginal. A textura superficial mostrou a menor concordância intraexaminador para todos os métodos testados. O método clínico direto e os dois métodos indiretos foram diferentes significativamente para todas as características analisadas $(p<0,05)$. Fotografias e modelos de gesso forneceram maiores médias ranqueadas do que o método clínico direto para integridade marginal e forma anatômica. As avaliações através de fotografias e modelos de gesso foram similares para todas as categorais avaliadas, exceto para textura superficial $(p<0,05)$. Conclusões: Todos os métodos foram diferentes para as características avaliadas. A maior concordância intraexaminador foi obtida com a avaliação através de modelos de gesso. Nenhum dos métodos foi adequado para avaliação da textura superficial.

Palavras-chave: Resina composta, superfície oclusal, critério USPHS, ensaio clínico.

\begin{abstract}
Aim: To compare different methods for evaluating composite resin restorations in posterior teeth and to evaluate the reliability of each method by determining the intraobserver agreement. Material and methods: 136 class I resin composite restorations were evaluated by a trained examiner using modified Ryge criteria to assess selected restoration characteristics with three different methods: clinical, photographic and dental cast models. Results: The results showed that intraexaminer agreement was better on dental cast models evaluations for marginal integrity and anatomic form and was similar between photographic and clinical evaluations for marginal integrity and marginal discoloration. Surface texture showed the lowest degree of intraexaminer agreement with all the methods tested. Direct clinical method and the two indirect methods were significantly different for all the characteristics assessed $(p<0.05)$. Photographs and dental cast models methods gave higher mean ranks than direct clinical method for marginal integrity and anatomic form. Photographs and dental cast models evaluations were similar for all the characteristics assessed, except for surface texture $(p<0.05)$. Conclusion: All of the methods were different for all the characteristics assessed. The highest Intraexaminer agreement was obtained from dental cast models evaluation. All the methods showed that are not adequate to evaluate surface texture.
\end{abstract}

Key words: Composite resin, oclusal surface, clinical study, USPHS criteria

Rev. Fac. Odontol. Porto Alegre, v. 53, n. 1, p. 21-26, jan./abr., 2012.
${ }^{1}$ Research fellow, Arequipa, Peru.

2 Associate Professor, Department of Social and Preventive Dentistry, Federal University of Rio Grande do Sul, Porto Alegre, RS, Brazil.

${ }^{3} \mathrm{PhD}$ Student, Faculty of Dentistry, Federal University of Rio Grande do Sul, Porto Alegre, RS, Brazil.

${ }^{4}$ Professor, Department of Social and Preventive Dentistry, Federal University of Rio Grande do Sul, Porto Alegre, RS, Brazil.

Correspondência: Prof. Marisa Maltz

Endereço: Faculdade de Odontologia, Universidade Federal do Rio Grande do Sul Rua Ramiro Barcelos, 2492 - CEP 90035-003, Porto Alegre - RS, Brasil

Fone: (51) 33085247

E-mail: marisa.maltz@gmail.com

Data de Submissão: 05/07/2012

Data de Aceite: 16/08/2012

\section{Introduction}

The use of resin-based composites for restoring posterior teeth has increased significantly in recent years (ERNEST et al., 2001; RYKKE, 1992; SUZUKI et al., 1995; TÜRKÜN; AKTENER, 2001), specially after the introduction of several modifications from the earlier generations (ABDALLA; ALHADAINY, 1996; ADA COUNCIL ON SCIENTIFIC AFFAIRS, 2003; HERVÁS-GARCÍA et al., 2006). In vitro tests of resin composite materials are essential during their development. However, the final decision about the acceptability of a dental restorative material for use in the mouth can only come from clinical observation (BAYNE et al., 1994; RYGE; SNYDER, 1973; RYGE, 1980; SÖDERHOLM, 1991; WILSON; WILSON; SMITH, 1985).

Several techniques have been developed to evaluate the quality of restorations. Direct clinical techniques are based on conventional dental examinations. The United States Public Health Service, or USPHS criteria - also known as Ryge criteria detailed the assessment of marginal adaptation, anatomic form, caries, color match and cavo-surface margin discoloration, providing four grades of criteria for each (RYGE; SNYDER, 1973; RYGE, 1980; RYGE, et al., 1981). The system has been frequently applied for clinical evaluation of the quality of composite resin restorations (ERNEST et al., 2001; ABDALLA; ALHADAINY, 1996; ADA COUNCIL ON SCIENTIFIC AFFAIRS, 2003; KNIBBS, 1997; LUNDIN; RASMUSSON, 2004; RASKIN et al., 1999; WILDER et al., 1991; YIP et al., 2003) and remains the preferred system for evaluating characteristics of dental restorations. The use of intra-oral color photography is a method largely used for evaluation of dental restorations, particularly when the marginal integrity, marginal discoloration and registration of color changes of composite resin restorations are to be studied (YIP et al., 2003; MAHLER; ENGLE; BRYANT, 1986). Indirect methods with stone cast replicas have also been used to assess anatomic form, marginal integrity and surface texture. They are either based on visual evaluations by dentists or physical measurements by machines (WINKLER et al., 1996). 
There are few studies comparing direct and indirect methods used for assessing dental restorations (KREULEN et al., 1993b; SMALES, 1983; SMALES; CREAVEN, 1985). Furthermore, the majority of clinical studies on assessment of restorations do not evaluate the reliability and sensitivity of these methods (references clinical studies). This paper presents a comparison between a direct (clinical evaluation) and two indirect methods (photographs and dental cast models evaluation) to assess their ability to discriminate between different degrees of deterioration of composite resin restorations in posterior teeth for marginal integrity, anatomic form, marginal discoloration and surface texture. Additionally, the reliability of each method was studied by determining the intraexaminer agreement.

\section{Materials e Methods}

One hundred and thirty six oclusal composite resin restorations in permanent molars (58 upper molars and 78 lower molars) were examined in 58 subjects in a clinical observational single-blind study. A rating scale was used to assess selected restoration characteristics with three different methods: direct clinical evaluation, photographic and dental cast models evaluations. The present study was submitted and approved by the Ethics Committee of the Federal University of Rio Grande do Sul and all the subjects signed an informed consent.

\section{Direct clinical evaluation method}

All restorations were evaluated according modified Ryge criteria [9] considering four characteristics: marginal integrity, anatomic form, marginal discoloration and superficial texture. For each characteristic a rating scale of four scores was considered: Alfa (A), Bravo (B), Charlie (C) and Delta (D). Alfa restorations are of satisfactory quality and meet all clinical standards with a range of excellence. Bravo restorations are also satisfactory, although not ideal, with a range of acceptability. Charlie restorations are not of acceptable quality and should be replaced or corrected and Delta restorations are not clinically acceptable (Table 1). All dental evaluations were carried out under a dental operating light, using plane mouth mirrors, dental explorers and air syringe.

\section{Photographic evaluation}

Color photographs of the restorations were taken using a 200/5.6 Medical Nikorr lens (Nikon Inc. USA) at x1.5 magnification to evaluate marginal integrity, anatomic form, marginal discoloration and superficial texture (Table 1). All photographs were taken using frontsurfaced mirrors, dental operating light and air syringe. As nearly as possible, all photographs were taken at right angles to the restored tooth surfaces.

\section{Dental cast models evaluations}

Impressions of the teeth of interest and the adjacent teeth were made using a polyvinyl siloxane impression material (Virtual, Ivoclar Vivadent, Liechtenstein) which were carried out with a dispenser in a disposable quadrant tray. Firstly, impressions were cleaned with alcohol and treated with a silicone relaxation liquid (Tensilab, Zhermack, Rovigo, Italy). After 24 hours, each one of the impressions was poured out with a hard rock plaster of white colour (GC Fuji Rock EP, GC America Inc. Alsip, IL, US) mixed with water under vacuum (Polidental Model A2167/06, Polidental Ind. e Com. Ltda, São Paulo, Brazil). The trays were poured out with plaster by means of a vibrator device (Knebel Produtos Dentários, Porto Alegre, RS, Brazil) and the material set under pressure (2 bar) in a pressurized device for at least 30 minutes. The stone replicas were evaluated regarding marginal integrity, anatomic form and surface texture (Table 1).
Table 1. Modified Ryge criteria for direct and indirect evaluation

\begin{tabular}{|c|c|c|}
\hline \multirow[t]{4}{*}{$\begin{array}{l}\text { Marginal } \\
\text { integrity }\end{array}$} & $A$ & $\begin{array}{l}\text { No visible evidence of crevice along the } \\
\text { margin }\end{array}$ \\
\hline & B & $\begin{array}{l}\text { Visible evidence of a crevice along the } \\
\text { margin into which the explorer will } \\
\text { penetrate }\end{array}$ \\
\hline & $C$ & The dentin or the base is exposed \\
\hline & $D$ & $\begin{array}{l}\text { The restoration is fractured, mobile or } \\
\text { missing }\end{array}$ \\
\hline \multirow[t]{3}{*}{$\begin{array}{l}\text { Anatomical } \\
\text { form }\end{array}$} & $A$ & $\begin{array}{l}\text { The restoration is continuous with } \\
\text { existing anatomical form }\end{array}$ \\
\hline & B & $\begin{array}{l}\text { The restoration is discontinuous with } \\
\text { existing anatomical form, but the } \\
\text { material is not sufficient to expose the } \\
\text { dentin or base }\end{array}$ \\
\hline & $\mathrm{C}$ & $\begin{array}{l}\text { Sufficient material lost to expose the } \\
\text { dentin or base }\end{array}$ \\
\hline larginal & $A$ & $\begin{array}{l}\text { No discoloration anywhere along the } \\
\text { margin between the restoration and } \\
\text { adjacent tooth }\end{array}$ \\
\hline
\end{tabular}

B Slight discoloration along the margin between the restoration and the adjacent tooth

C The discoloration penetrated along the margin of the restorative material in a pulpal direction

\begin{tabular}{|c|c|c|}
\hline \multirow[t]{3}{*}{$\begin{array}{l}\text { Surface } \\
\text { texture }\end{array}$} & $A$ & $\begin{array}{l}\text { The restoration surface is as smooth as } \\
\text { the surrounding enamel }\end{array}$ \\
\hline & $B$ & $\begin{array}{l}\text { The restoration surface is rougher than } \\
\text { the surrounding enamel }\end{array}$ \\
\hline & C & $\begin{array}{l}\text { There is a crevice and fracture on the } \\
\text { surface of the restoration }\end{array}$ \\
\hline
\end{tabular}

A, Alfa; B, Bravo; C, Charlie; D, Delta

Evaluations of the replicas were carried out by visual and tactile inspection using a stereomicroscope (Metrimpex, Hungary) with a x1.6 magnification, dental explorer and a pointed white lighting source.

Training

All the exams were carried out by the same operator (KP). Before the beginning of the examinations, the examiner undertook a special calibration training program in evaluating restorations using the direct and indirect evaluation methods. The training consisted of: (1) review and discussion of the criteria, (2) performance of a series of practice examinations using cast dental models, photographs, extracted teeth and clinical evaluation of 27 teeth with time interval $\geq$ week between the exams.

\section{Examiner reliability}

All the composite resin restorations, color photographs and cast models were evaluated twice within an interval of at least one week.

\section{Statistical analysis}

Kappa statistics (Cohen's kappa and unweighted kappa) was used to compare duplicate evaluations of clinical, photographic 
and dental cast models for each assessed characteristic. Friedman repeated measures analysis of variance by rank and Wilcoxon signranked test for pair-wise comparison was used for data analysis. The probability level for statistical significance was set at $\alpha \leq 0.05$. The data was analyzed using the Statistical Package for Social Science (SPSS) version 13.0.

\section{Resultados}

Table 2 shows the values of reliability characteristics for the direct and indirect methods. The intraexaminer reliability was evaluated using Kappa statistics (unweighted Kappa and Cohen's

Table 2. Intra-examiner reliability characteristics of the direct (clinical) method and indirect methods (photographs and dental cast models) for assessment of marginal integrity, anatomic form, marginal discoloration and surface texture

\begin{tabular}{|c|c|c|c|c|}
\hline \multirow[b]{2}{*}{ Method } & \multicolumn{4}{|l|}{ Criteria } \\
\hline & Marginal Integrity & Anatomic Form & Marginal Discoloration & Surface Texture \\
\hline
\end{tabular}

\begin{tabular}{|c|c|c|c|c|c|c|c|c|}
\hline Clinic & Value & Interpretation & Value & Interpretation & Value & Interpretation & Value & Interpretation \\
\hline $\begin{array}{l}\text { Unweighted } \\
\text { Kappa }\end{array}$ & 0,6 & Substantial & 0.6 & Substantial & 0.7 & Substantial & 0.4 & Moderate \\
\hline $\begin{array}{l}\text { Percentage } \\
\text { agreement }\end{array}$ & $81.1 \%$ & - & $80.0 \%$ & - & $84.4 \%$ & - & $70.8 \%$ & - \\
\hline $\begin{array}{l}\text { Cohen's } \\
\text { Kappa }\end{array}$ & 0.8 & $\begin{array}{l}\text { Almost } \\
\text { perfect }\end{array}$ & 0.7 & Substantial & 0.6 & Substantial & 0.7 & Substantial \\
\hline $\begin{array}{l}\text { Percentage } \\
\text { agreement }\end{array}$ & $97.0 \%$ & - & $97.0 \%$ & - & $97.0 \%$ & - & $98.0 \%$ & - \\
\hline
\end{tabular}

Photographs

Unweighted

Kappa

Percentage agreement

Cohen's

Kappa

Percentage agreement

0.6

Substantial

0.7

Substantial

0.7

Substantial

0.5

Moderate

$85.3 \% \quad-$

Almost

$91.2 \% \quad-$

Almost
perfect

$97.8 \%-$

0.8 $\quad$ Almost

$83.8 \% \quad-$

$72.8 \%$

$0.5 \quad$ Moderate

$0.5 \quad$ Moderate

$97.0 \%$

$96.3 \%$

$76.5 \%$

Dental cast

models

Unweighted

Kappa

Percentage

agreement

Cohen's

Kappa

Percentage agreement

0.7

Substantia

0.8

perfect

$92.6 \% \quad-$

Almost

perfect

$96.3 \%$

-

0.9 perfect

$99.3 \% \quad-$

$99.3 \%-$

Table 3 compares the direct clinical observations of composite resin restorations with the indirect observations of photographs and dental cast models. The results were significantly different between the direct clinical method and the two indirect methods for all the characteristics assessed $(p<0.05)$ for marginal

Kappa) and percentage of agreement. Dental cast models evaluations
obtained better Kappa values for marginal integrity and anatomic form

Kappa) and percentage of agreement. Dental cast models evaluations values obtained were similar between photographs and dental cast

Kappa values were similar between photographic and clinical evaluations for marginal integrity and marginal discoloration. methods. Surface texture showed the lowest kappa values and degree of intraexaminer agreement for all the methods tested. However, Kappa values were better for anatomic form and surface 
Table 3. Comparison of clinical, photographic and dental cast models evaluation methods for marginal integrity, anatomic form, marginal discoloration and surface texture

\begin{tabular}{|c|c|c|c|c|c|c|c|}
\hline \multirow[b]{3}{*}{ Criteria } & \multirow[b]{3}{*}{ Scores } & \multicolumn{6}{|c|}{ Evaluation methods } \\
\hline & & \multicolumn{2}{|c|}{ Clinic } & \multicolumn{2}{|c|}{ Photographs } & \multirow{2}{*}{$\begin{array}{l}\begin{array}{l}\text { Dental } \\
\text { models }\end{array} \\
\mathrm{n} \\
\end{array}$} & \multirow{2}{*}{$\begin{array}{l}\text { cast } \\
\% \\
\end{array}$} \\
\hline & & $\mathrm{n}$ & $\%$ & $\mathrm{n}$ & $\%$ & & \\
\hline \multirow[b]{5}{*}{$\begin{array}{l}\text { Marginal } \\
\text { integrity }\end{array}$} & $A$ & 72 & 52.9 & 16 & 11.8 & 4 & 2.9 \\
\hline & $\mathrm{B}$ & 55 & 40.4 & 104 & 76.5 & 121 & 89.0 \\
\hline & C & 4 & 2.9 & 8 & 5.9 & 5 & 3.7 \\
\hline & $\mathrm{D}$ & 5 & 3.7 & 8 & 5.9 & 6 & 4.4 \\
\hline & $\begin{array}{l}\text { Total } \\
\text { Mean } \\
\text { rank }\end{array}$ & \multicolumn{2}{|c|}{$1.54^{\mathrm{B}}$} & \multicolumn{2}{|l|}{$2,20^{A}$} & \multicolumn{2}{|l|}{$2,26^{\mathrm{A}}$} \\
\hline \multirow[b]{4}{*}{$\begin{array}{l}\text { Anatomic } \\
\text { form }\end{array}$} & $A$ & 76 & 56.3 & 12 & 8.9 & 3 & 2.2 \\
\hline & B & 52 & 38.5 & 109 & 80.7 & 122 & 90.4 \\
\hline & $\mathrm{C}$ & 8 & 5.9 & 15 & 11.0 & 11 & 8.1 \\
\hline & $\begin{array}{l}\text { Total } \\
\text { Mean } \\
\text { rank } \\
\end{array}$ & \multicolumn{2}{|c|}{$1.48^{\mathrm{B}}$} & \multicolumn{2}{|l|}{$2.24^{\mathrm{A}}$} & $\begin{array}{r}136 \\
2.28^{\mathrm{A}} \\
\end{array}$ & 100 \\
\hline \multirow{4}{*}{$\begin{array}{l}\text { Marginal } \\
\text { discoloration* }\end{array}$} & A & 92 & 67.6 & 61 & 44.9 & & \\
\hline & $B$ & 39 & 28.7 & 70 & 51.5 & & \\
\hline & $\mathrm{C}$ & 5 & 3.7 & 5 & 3.7 & & \\
\hline & Total & 136 & 100 & 136 & 100 & & \\
\hline \multirow[b]{4}{*}{$\begin{array}{l}\text { Surface } \\
\text { texture }\end{array}$} & A & 102 & 75.0 & 16 & 11.8 & 42 & 30.9 \\
\hline & $B$ & 29 & 21.3 & 17 & 12.5 & 18 & 13.2 \\
\hline & $\mathrm{C}$ & 5 & 3.7 & 103 & 75.7 & 76 & 55.9 \\
\hline & $\begin{array}{l}\text { Total } \\
\text { Mean } \\
\text { rank }\end{array}$ & \multicolumn{2}{|c|}{$1.31^{\mathrm{C}}$} & \multicolumn{2}{|l|}{$2.52^{\mathrm{A}}$} & $\begin{array}{l}136 \\
2.17^{B}\end{array}$ & 100 \\
\hline
\end{tabular}

Mean ranks followed by different prints are significantly different using non-parametric Friedman test complemented by multiple comparisons $(p<0.05)$

* Non-parametric Wilcoxon test $(p<0.01)$

\section{Discussion}

This study demonstrated that the indirect methods using dental cast models have higher intraexaminer agreement while clinical and photographic evaluations showed similar values for most of the characteristics assessed.

The intraexaminer agreement for the assessment of surface texture was low for all the methods. According to the literature, clinical evaluation of surface texture is difficult, especially with regards to reproducibility, and should be evaluated on replica models using sophisticated measuring devices to obtain precise data (HICKEL et al., 2007). The surface texture evaluation has been extremely used in the assessment of dental restorations (RYGE, 1980; CHANDLER et al., 1973; SMALES; CREAVEN, 1979). However, as surface proved to be highly susceptible to examiner drift, the withdrawal of this characteristic from the USPHS criteria has been proposed (CVAR; RYGE, 2005).

Frequently used indexes for interexaminer and intraexaminer agreement are the percentage agreement and Pearson's correlation coefficient. These indexes may be misleading, since they do not consider the proportion of disagreement beyond chance. Thus, Kappa statistics were therefore chosen (HUDSON, 2004).

In this study, the intraexaminer agreement was evaluated using Cohen's Kappa and unweighted Kappa. The Kappa statistic is a measure of the proportion of agreement beyond chance which is actually achieved. Kappa values between 0.4 and 0.79 represent moderate to substantial agreement beyond chance. Values less than 0.4 represent poor agreement beyond chance Cohen's Kappa statistics is used by the majority of the researchers to analyze intra and interexaminer reliability (YIP et al., 2003; SAKRANA et al., 2004). However, Cohen's Kappa does not evaluate reliability adequately in extended rating scales because of his dichotomy it is necessary to stipulate "cut off points" to define "acceptable" and "unacceptable" restorations. Thus, great intra and interexaminer disagreements are considered agreements and Cohen's Kappa overestimate reliability related to unweighted Kappa. The use of this type of statistic could lead to inadequate conclusions due to overestimation of the agreement values (BRUNTHALER et al., 2003). This fact was verified in the present study showing better Cohen's Kappa values than unweighted Kappa intraexaminer agreement values for all the characteristics, except for marginal discoloration, since the difference between Bravo (B) and Charlie (C) scores is tiny leading to the increase in the diagnose error for the Alfa (A) - Bravo (B) junction.

The results in this study showed that both of the two indirect methods allowed more critical observations of the restorations than the direct clinical method, a finding also reported by other authors (KREULEN et al., 1993b; YIP et al., 2003; LEINFELDER et al., 1986; SMALES, 1983; SMALES; CREAVEN, 1985; BRYANT, 1990; TÜRKÜN; AKTENER; ATES, 2003). Higher scores were obtained from the indirect methods assessments (photographs and dental cast models) for marginal integrity and anatomic form. Photographic evaluations also showed higher scores than direct clinical evaluations for marginal discoloration. In the present study, a high number of restorations were ranked as faulty through photographic and dental cast models evaluations. However, this finding should be considered carefully since the reproducibility in the assessment of this characteristic was low.

Most researchers use the USPHS criteria (RYGE, 1980) for assessment of restorations. Ryge developed this rating scale in the seventies as a standardized method to clinically evaluate restorations. The criteria were drawn up at a time when the longevity of direct restorative materials was limited; deterioration and inadequacies of these materials were more pronounced, and defects appeared earlier than with present-day materials. Nowadays, the majority of restorations in many studies continue to receive an Alpha score at relative small periods of time evaluations (ERNEST et al., 2001; TÜRKÜN; AKTENER; ATES, 2003; YIP et al., 2003). In order to detect early deterioration and differences between restorations it would be helpful to have a more discriminative scale (HICKEL et al., 2007) or more objective ranking methods. These include the use of intraoral photography (MAHLER; ENGLE; BRYANT, 1986; SMALES, 1983; SMALES; CREAVEN, 1985; KREULEN et al., 1993a); impressions (KREULEN et al., 1993b; JOKSTAD; MJÖR, 1991); dental cast models (BAYNE et al., 1994; LEINFELDER et al., 1986); stereo microscope (LAMBRECHTS et al., 1984), commercial and customized profilometers (LEINFELDER et al., 1986); computerized three-dimensional measuring microscope (DUPERON; NEVILE; KASLOFF, 1971); three-dimensional laser digitizer (PERRY et al., 2000). The use of dental photographs and cast dental models 
contributed significantly to a more accurate interpretation. Yip and colleagues (YIP et al., 2003) evaluating resin-based composites observed that small discrete marginal discolorations and discrepancies in marginal integrity were detected more readily from the photographs and replicas, respectively, than from the direct clinical examinations. The indirect methods produce a permanent record of the restorations and the raw data is always available for reexamination, change in evaluators or modification in evaluation methods (TÜRKÜN; AKTENER; ATES, 2003; SMALES, 1983; KREULEN et al., 1993a; JOKSTAD; MJÖR, 1991). However, the photographic recording and the replica method are not optimal in field trials since these techniques are time-consuming. Dental cast models replicas are also expensive, presents storage problems and do not allowed gingival and proximal tooth surfaces examinations (SMALES; CREAVEN, 1985).

Furthermore, it is important to point out that the direct clinical method can discriminate between acceptable and unacceptable restorations. According to Ryge (1980), a restoration that achieve Charlie (C) score is not anymore of acceptably quality and should be replaced. In this investigation, no difference was observed among the methods when the cut of point was between Bravo (B) and Charlie (C).

This study demonstrated that the intraexaminer agreement was high for the assessment of marginal integrity and anatomic form using dental cast models and was similar between clinical and photographic evaluation for marginal integrity and marginal discoloration. For surface texture, the intraexaminer agreement was low for all the methods, showing its inadequacy.

There were significant differences between the direct clinical method and the indirect methods for all the composite resin restorations characteristics assessed. The indirect methods allowed more detailed and critical observations. However, the direct clinical method was able to distinguish between clinical acceptable and unacceptable restorations.

\section{Acknowledgments}

We acknowledge the support of CAPES, CNPq (40.3420/04$0)$, FAPERGS (04/1531-8), and the industries Ivoclar/Vivadent (Schaan, Liechtenstein) and Hu-Friedy (Chicago IL, USA).

\section{References}

ABDALLA, A.I.; ALHADAINY, H.A. 2-year clinical evaluation of Class I posterior composites. Am. J. Dent., San Antonio, TX, v. 9, no. 4, p. 150-152, Aug. 1996.

AFFAIRS, A.C.O.S. Direct and indirect restorative materials. J. Am. Dent. Assoc., Chicago, v. 134, no. 4, p. 463-472, Apr. 2003.

BAYNE, S.C. et al. Confirmation of Leinfelder clinical wear standards. Dent. Mater., Copenhagen, v. 10, no. 1, p. 11-18, Jan. 1994.

BRUNTHALER, A. Longevity of direct resin composite restorations in posterior teeth. Clin. Oral Investig., Berlin, v. 7, no. 2, p. 63-70, June 2003.

BRYANT, R.W. Comparison of three standards for quantifying occlusal loss of composite restorations. Dent. Mater., Copenhagen, v. 6, no. 1, p. 60-62, Jan. 1990.
CHANDLER, H.H. et al. Clinical evaluation of a radiopaque composite restorative material after three and a half years. J. Dent. Res., Chicago, v. 52, no. 5, p. 1128-1137, Sept./Oct. 1973.

CVAR, J.F.; RYGE, G. Reprint of criteria for the clinical evaluation of dental restorative materials. 1971. Clin. Oral Investig., Berlin, v. 9, no. 4, p. 215-232, Dec. 2005.

DUPERON, D.F.; NEVILE, M.D.; KASLOFF, Z. Clinical evaluation of corrosion resistance of conventional alloy, spherical-particle alloy, and dispersion-phase alloy. J. Prosthet. Dent., St. Louis, v. 25, no. 6, p. 650-656, June 1971.

ERNST, C.P. et al. Clinical performance of a packable resin composite for posterior teeth after 3 years. Clin. Oral Investig., Berlin, v. 5, no. 3, p. 148-155, Sept. 2001.

HERVÁS-GARCÍA, A. et al. Composite resins. A review of the materials and clinical indications. Med. Oral Patol. Oral Cir. Bucal, Valencia, v. 11, no. 2, p. E215-E220, Mar. 2006.

HICKEL, R. et al. Recommendations for conducting controlled clinical studies of dental restorative materials. Clin. Oral Investig., Berlin, v. 11, no. 1, p. 5-33, Mar. 2007.

HUDSON, P. Conservative treatment of the Class I lesion: a new paradigm for dentistry. J. Am. Dent. Assoc., Chicago, v. 135, no. 6, p. 760-764, June 2004.

JOKSTAD, A.; MJÖR, I.A. Assessment of marginal degradation of restorations on impressions. Acta Odontol. Scand., London, v. 49, no. 1 , p. 15-25, Feb. 1991.

KNIBBS PJ. Methods of clinical evaluation of dental restorative materials. J. Oral Rehabil., Oxford, v. 24, no. 2, p. 109-123, Feb.

KREULEN, C. M. et al. Evaluation of occlusal marginal adaptation of Class II resin-composite restorations. ASDC J. Dent. Child., Chicago, v. 60 , no. $4-5$, p. 310-314, July/Oct. 1993a.

KREULEN, C.M. et al.Comparison of two methods for evaluating the occlusal marginal adaptation of posterior restorations. ASDC J. Dent. Child., Chicago, v. 60, no. 4-5, p. 304-309, July/Oct. 1993b.

LAMBRECHTS, P. et al. Quantitative evaluation of the wear resistance of posterior dental restorations: a new three-dimensional measuring technique. J. Dent., Kidlington, v. 12, no. 3, p. 252-267, Sept. 1984.

LEINFELDER, K.F. et al. Quantitative wear measurement of posterior composite resins. Dent. Mater., Copenhagen, v. 2, no. 5, p. 198-201, Oct. 1986.

LUNDIN, S.A.; RASMUSSON, C.G. Clinical evaluation of a resin composite and bonding agent in Class I and II restorations: 2-year results. Quintessence Int., Berlin, v. 35, no. 9, p. 758-762, Oct. 2004.

MAHLER, D.B.; ENGLE, J.H.; BRYANT, R.W. Standardizing evaluations of the clinical marginal fracture of amalgam. J. Dent. Res., Chicago, v. 65, no. 8, p. 1108-1111, Aug. 1986.

PERRY, R. et al. Composite restoration wear analysis: conventional methods vs. three-dimensional laser digitizer. J. Am. Dent. Assoc., Chicago, v. 131, no. 10, p. 1472-1477, Oct. 2000. 
RASKIN, A. et al. Clinical evaluation of a posterior composite 10-year report. J. Dent., Kidlington, v. 27, no. 1, p. 13-19, Jan. 1999.

RYGE, G. et al. Standardization of clinical investigators for studies of restorative materials. Swed. Dent. J., Jonkoping, v. 5, no. 5-6, p. 235239, 1981.

RYGE, G.; SNYDER, M. Evaluating the clinical quality of restorations. J. Am. Dent. Assoc., Chicago, v. 87, no. 2, p. 369-377, Aug. 1973.

RYGE, G. Clinical criteria. Int. Dent. J., London, v. 30, no. 4, p. 347358, Dec. 1980.

RYKKE, M. Dental materials for posterior restorations. Endod. Dent. Traumatol., Copenhagen, v. 8, no. 1, p. 139-148, Aug. 1992.

SAKRANA, A.A. et al. One-year clinical evaluation of two composite materials used for anterior class $\mathrm{V}$ restorations. J. Oral Rehabil., Oxford, v. 31, no. 10, p. 985-990, Oct. 2004.

SMALES, R.J.; CREAVEN, P.J. Evaluation of clinical methods for assessing the surface roughness of restorations. J. Prosthet. Dent., St. Louis, v. 42, no. 1, p. 45-52, July 1979.

SMALES, R.J.; CREAVEN, P.J. Evaluation of three clinical methods for assessing amalgam and resin restorations. J. Prosthet. Dent., St. Louis, v. 54, no. 3, p. 340-346, Sept. 1985.

SMALES, R.J. Evaluation of clinical methods for assessing restorations. J. Prosthet. Dent., St. Louis, v. 49, no. 1, p. 67-70, Jan. 1983.

SÖDERHOLM, K.J. Correlation of in vivo and in vitro performance of adhesive restorative materials: a report of the ASC MD156 Task Group on Test Methods for the Adhesion of Restorative Materials. Dent. Mater., Copenhagen, v. 7, no. 2, p. 74-83, Apr. 1991.

SUZUKI, S. Effect of particle variation on wear rates of posterior composites. Am. J. Dent., San Antonio, TX, v. 8, no. 4, p. 173-178, Aug. 1995.

TÜRKÜN L.S., AKTENER, B.O. Twenty-four-month clinical evaluation of different posterior composite resin materials. J. Am. Dent. Assoc., Chicago, v. 132, no. 2, p.196-203, 2001.

TÜRKÜN, L.S.; AKTENER, B.O.; ATES, M. Clinical evaluation of different posterior resin composite materials: a 7-year report. Quintessence Int., Berlin, v. 43, no. 6, p. 418-426, June 2003.

WILDER, A.D. Five-year clinical study of u.v.-polymerized posterior composites. J. Dent., Kidlington, v. 19, no. 4, p. 214-220, Aug. 1991.

WILSON, N.H.; WILSON, M.A.; SMITH, G.A. A clinical trial of a new visible light-cured composite restorative-- initial findings and one-year results. Quintessence Int., Berlin, v. 16, no. 4, p. 281-290, Apr. 1985.

WINKLER, M.M. et al. Visual versus mechanical wear measurement of dental composite resin. J. Oral Rehabil., Oxford, v. 23, no. 7, p. 294-500, July 1996.

YIP, K.H. et al. Clinical evaluation of packable and conventional hybrid resin-based composites for posterior restorations in permanent teeth: results at 12 months. J. Am. Dent. Assoc., Chicago, v. 134, no. 12, p. 1581-1589, Dec. 2003.

Rev. Fac. Odontol. Porto Alegre, v. 53, n. 1, p. 21-26, jan./abr., 2012. 